\title{
Karakteristik Desain Poster Film Animasi Amerika Serikat
}

\author{
Aniendya Christianna ${ }^{1}$ dan Moeljadi Pranata ${ }^{2}$ \\ ${ }^{1}$ Jurusan Desain Komunikasi Visual, Fakultas Seni dan Desain \\ Universitas Kristen, Surabaya \\ E-mail: aniendya@peter.petra.ac.id \\ 2Program Studi Desain Komunikasi Visual, Jurusan Seni dan Desain \\ Fakultas Sastra, Universitas Negeri Malang
}

\begin{abstract}
Abstrak
Sebaik apa pun sebuah film animasi jika tanpa didukung media untuk menggaungkan pesan dari film tersebut akan berakhir sia-sia. Salah satu media iklan terpenting dalam mempromosikan sebuah film animasi adalah poster. Karena poster film animasi merupakan media terdepan yang berhadapan langsung dengan target audiens dalam menyampaikan informasi film sebelum pemutaran film berlangsung. Sehingga visualisasi poster yang mencakup komposisi bahasa verbal dan non verbal patut mendapat perhatian yang lebih dalam perancangannya.
\end{abstract}

Kata kunci: Poster, film animasi, semiotika visual.

\begin{abstract}
An animated film will end in vain no matter how well it is without the support of media to give buzz to the message of the film. One of the most important advertising media in promoting an animated film is the poster. Because the animation movie poster is the leading medium which deals directly with the target audience in delivering information about the film before the screening of the film takes place. So visualization of the poster that includes the composition of verbal and non verbal language deserves more attention in its design.
\end{abstract}

Keywords: Poster, animation movie, visual semiotics.

\section{Pendahuluan}

Dewasa ini, atmosfer film animasi di dunia sangat menyenangkan dan diminati oleh seluruh lapisan masyarakat, mulai dari usia kanak-kanak hingga dewasa. Banyaknya aplikasi animasi ke berbagai media untuk beragam keperluan seperti dalam film, iklan, video klip, presentasi multimedia, website, bumpers dan lain sebagainya menjadikan animasi dapat dinikmati melalui beragam media dan oleh siapa pun.

Berkat jasa Walt Disney, film jenis ini tampil sebagai tontonan yang sangat populer, baik melalui layar lebar maupun televisi. Melalui karakter legendarisnya, Mickey Mouse dan Donald Duck, film animasi kemudian lebih dikenal sebagai film kartun. Kata kartun berasal dari Bahasa Inggris "cartoon' yang berarti gambar lucu. Jadi sebutan film kartun sebenarnya hanya tepat untuk film-film seperti produk Walt Disney, yang memang menampilkan tokoh-tokoh dengan bentuk, perilaku dan dialog yang lucu. Film animasi telah mengalami perkembangan luar biasa. Baik dari sisi tema maupun teknik pencitraan.

\section{Perkembangan Film Animasi Amerika Serikat}

Pada umumnya masyarakat lebih mengenal istilah film kartun dibandingkan film animasi. Film jenis ini juga selalu dikonotasikan sebagai tontonan yang lucu dan menghibur. Semua itu tak lepas dari dari sejarah kelahirannya. Riwayat film animasi sama tua dengan sejarah gambar hidup itu sendiri. Berkat jasa Walt Disney, film jenis ini tampil sebagai tontonan yang populer, baik melalui layar lebar maupun televisi. Melalui karakter legendarisnya, Mickey Mouse dan Donald Duck, film animasi kemudian lebih dikenal sebagai film kartun. Kata kartun berasal dari Bahasa Inggris "cartoon' yang berarti gambar lucu. Jadi sebutan film kartun sebenarnya hanya tepat untuk film-film seperti produk Walt Disney, yang memang menampilkan tokoh-tokoh dengan bentuk, perilaku dan dialog yang lucu. Film animasi telah mengalami perkembangan luar biasa. Kini tema film animasi tidak selalu lucu. Walt Disney pernah merajai pasaran animasi dengan memproduksi tema-tema mengharukan seperti: Cinderella, The Hunchback of Notterdam, Snow White and the 7 Dwarfs, Slepping Beauty 
dan Alice in Wonderland. Bahkan tak sedikit pula film animasi yang menampilkan kisah petualangan yang menegangkan, contohnya Shrek, Titan A.E. dan Atlantis: The Lost Empire.

Perkembangan film animasi selama 10 tahun terakhir mengalami perkembangan yang sangat pesat, baik dari segi kuantitas maupun segi variasi. Perkembangan variasi film animasi dapat meliputi aspek cerita, teknik yang digunakan dan pencitraan film animasi (gaya visual). Perkembangan yang pesat tersebut salah satu faktor penyebabnya adalah masuknya kategori The Best Animated Feature pada penghargaan bergengsi skala internasional dan sangat eksklusif dalam dunia perfilman, yakni Academy Award Event (Oscar Award) pada tahun 2001 (http://www. movie- winners.com). Fenomena tersebut menjadi pemicu sutradara dan animator di seluruh dunia untuk berkompetisi memproduksi film animasi.

\section{Poster Film Animasi}

Namun, patut diperhatikan bahwa sebaik apa pun sebuah film animasi jika tanpa didukung media untuk menggaungkan pesan dari film tersebut akan berakhir sia-sia. Media promosi tersebut dapat berupa iklan. Iklan mampu berkomunikasi baik secara verbal maupun non verbal bergantung pada jenis media apa iklan tersebut dimunculkan, produk yang diiklankan dan target audiens produk yang bersangkutan.

Salah satu media iklan terpenting dalam mempromosikan sebuah film animasi adalah poster. Graphics Art Encyclopedia (1992: 397) mendefinisikan poster sebagai:

A large display sign of a product or a scene, printed on a board/fine paper, depending on the use. These large placards are used for sales promotion and to make announcement of activities that are of interest to a large number of people. They are versatile communication tools with many uses.

Jika diterjemahkan secara bebas maka kutipan di atas berarti cetakan yang relatif luas ataupun display suatu produk ataupun peristiwa pada sebuah papan ataupun kertas yang sering berisi ilustrasi, iklan, maupun pengumuman untuk mengkomunikasikan sesuatu dan sekaligus menarik perhatian orang lain. Fungsi poster tidak terbatas hanya pada mengkomunikasikan sesuatu dari produsen kepada konsumen, melainkan juga harus mampu meningkatkan bakat estetik, yakni memberikan bantuan pada kesadaran artistik kebudayaan dan sesama manusia. Dengan demikian sebuah poster harus menarik perhatian, ingatan, kepentingan atau setidaknya sifat ingin tahu seseorang.

Poster film animasi merupakan media terdepan dalam menyampaikan informasi film serta berhadapan langsung dengan target audiens sebelum pemutaran film berlangsung. Dengan kata lain, poster film animasi menduduki posisi sebagai ujung tombak film animasi. Sehingga visualisasi poster yang mencakup komposisi bahasa verbal dan non verbal (ilustrasi, warna, tipografi dan tata letak.) patut mendapat perhatian yang lebih dalam perancangannya.

\section{Semiotika Visual: Tanda dan Makna}

Semiotik merupakan suatu cara untuk memahami sistem hubungan yang biasa disebut dengan "tanda". Dengan kata lain semiotik mempelajari hakikat keberadaan suatu tanda dan kemudian membentuk persepsi manusia, lebih dari sekedar merefleksikan realitas dan fenomena yang ada.

Semiotik untuk studi media massa ternyata tak hanya terbatas sebagai kerangka teori, namun sekaligus juga dijadikan sebagai metode analisis sebagaimana diungkapkan oleh Hamad (Sobur, 2009: 114). Pierce dalam teorinya menggunakan teori segitiga makna (triangle meaning), yang terdiri atas sign (tanda), object (objek) dan interpretant (interpretan). Apabila ketiga elemen makna itu berinteraksi dalam benak seseorang, maka muncullah makna tentang sesuatu yang diwakili oleh tanda tersebut. Tanda terdapat di mana-mana; kata adalah tanda, demikian pula isyarat, lampu lalu lintas, bendera dan sebagainya. Dengan kata lain, segala sesuatu dapat menjadi tanda.

\section{Tinjauan Desain Poster Film Animasi Amerika Serikat}

Pada tahun 2000 Walt Disney Pictures memproduksi film animasi berjudul Dinosaur. Film ini merupakan kombinasi live actions background dengan komputer animasi makhluk-makhluk purbakala, terutama pada binatang jenis dinosaurus.

Film ini sukses menjadi box office pada tahun peluncurannya dengan meraup keuntungan yang sangat besar, dimana keuntungan tersebut mampu menutup semua biaya produksi dan marketing (http://www.allmovie.com). 


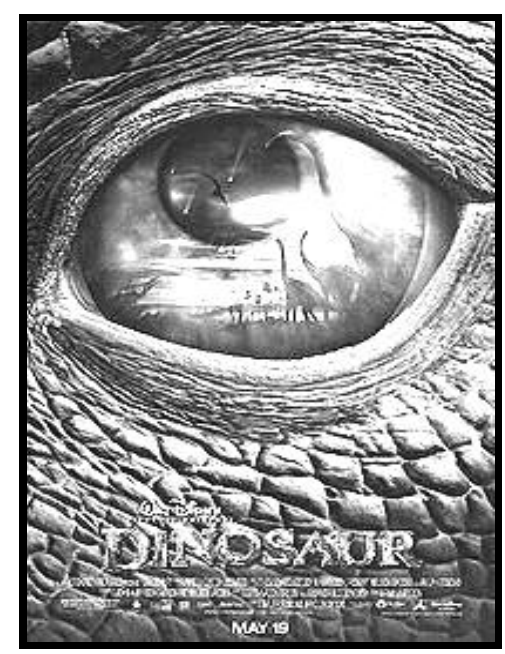

Sumber: www.movieposters.com

\section{Gambar 1. Poster Film Animasi Dinosaur (2000)}

Setelah merancang peta sederhana dari tiap elemen yang membentuk poster film animasi tersebut, dapat diketahui bahwa layout desain poster bersifat teratur, simetris dan seimbang. Dalam desain poster tersebut, bidang poster dibagi menjadi dua bagian, yaitu bagian atas merupakan ilustrasi dan bagian bawah merupakan bagian judul dan credit title. Secara keseluruhan didominasi oleh ilustrasi extreme close up, yakni salah satu mata dinosaurus.

Ilustrasi merupakan pusat perhatian dari poster tersebut, sebab sebagian besar bidang poster didominasi oleh ilustrasi. Adanya sudut pengambilan yang extreme close up dalam ilustrasi tersebut menjadi kekuatan utama dalam penyajiannya, yakni seolah-olah nyata dan detil. Penggunaan warna yang gelap menyesuaikan dengan warna dan tekstur kulit dinosaurus.

Tipografi judul masih tetap mempertahankan penggunaan uppercase secara keseluruhan. Dengan tujuan, agar judul tersebut memiliki kesan yang kuat dan terbaca dengan jelas. Dalam judul poster film animasi ini, typeface yang digunakan berasal dari kelompok old style. Diindikasikan oleh serif yang cenderung lebih tipis dari kelompok humanist dan tebal tipisnya stem/stroke tidak terlalu kontras.

Tipografi credit title merupakan kombinasi uppercase dan lowercase. Penyajian dalam format center untuk menghadirkan kesan yang teratur dan "seolah-olah" simetris. Ukuran typeface credit title disajikan semakin ke bawah semakin mengecil, kemudian besar kembali pada bagian bawah. Yakni pada penulisan "May 19", merupakan informasi waktu peluncuran perdana film animasi tersebut.
Warna yang digunakan banyak didominasi oleh warna gelap seperti coklat. Selain itu, dikombinasikan warna biru dan putih pada bagian dalam mata untuk memberikan aksentuasi terhadap objek utama.

Adapun tanda-tanda pada poster yang mengacu pada kehidupan binatang purba (dinosaurus), antara lain ilustrasi didominasi warna coklat yang bertekstur kasar. Ilustrasi tersebut mengarah pada permukaan kulit binatang purba yang cenderung kasar dan berwarna gelap. Demikian pula dengan tipografi judul yang menggunakan warna dan tekstur senada, tanpa mengabaikan emphasis judul ditengah-tengah ilustrasi yang padat. Extreme close up salah satu mata dinosaurus, mengartikan tentang audiens yang diajak lebih dekat untuk melihat dan mengamati kehidupan binatang purbakala melalui alur cerita fabel.

Dari ulasan dari tanda-tanda yang ada pada poster film animasi Dinosaur, dapat diintepretasikan bahwa terdapat satu garis besar tema, yakni kehidupan purbakala, lebih tepatnya kehidupan binatang purba jenis dinosaurus. Kehidupan purbakala tersebut merupakan hal yang tidak mungkin untuk diamati secara langsung. Karena masa tersebut telah berlalu dan menjadi punah. Oleh karena itu, kehadiran film animasi dengan berbagai teknologi didalamnya, memampukan audiens mengamati kehidupan dinosaurus mendekati realitas yang ada.

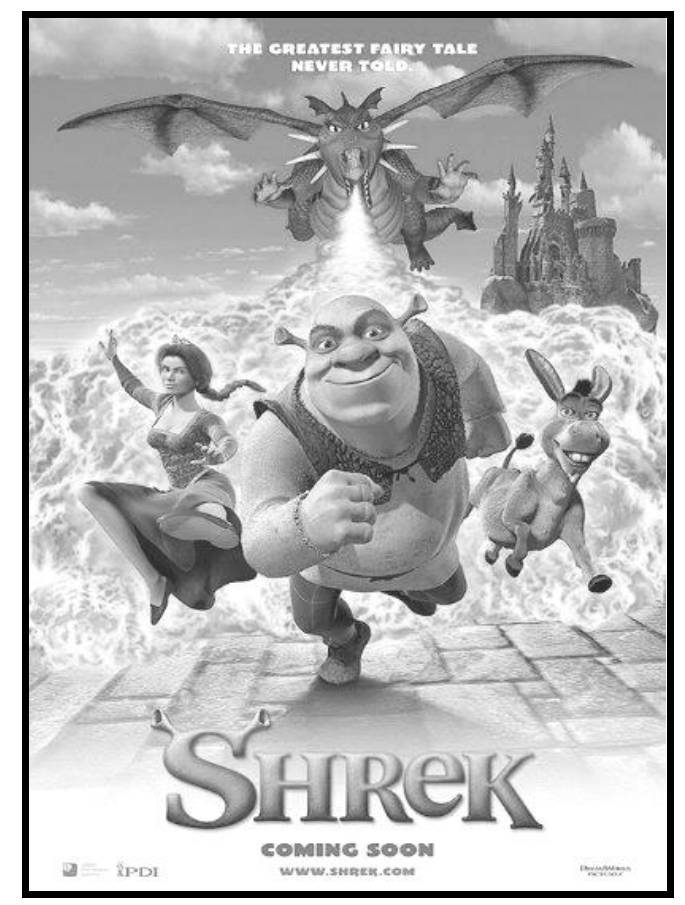

Sumber: www.movieposters.com

Gambar 2. Poster Film Animasi Shrek (2001) 
Shrek masuk dalam kategori animasi terbaik dalam Cannes Film Festival pada tahun 2001, dimana festival ini merupakan ajang penghargaan film-film terbaik berskala internasional. Pada puncaknya, Shrek juga meraih penghargaan tertinggi pada kategori Best Animated Feature mengalahkan Monster, Inc dan Jimmy Neutron pada tahun yang sama.

Lebih jauh tentang desain poster, layout desain tampak simetris dan teratur. Poster ini mengandalkan ilustrasi sebagai kekuatan utama dalam penyajiannya. Dengan peletakkan ilustrasi pada bagian atas, kemudian bagian bawah memuat judul dan credit title.

Ilustrasi yang dibuat secara komputerisasi ini merupakan pusat perhatian dari poster film animasi diatas. Sebab sebagian besar bidang poster diisi oleh ilustrasi. Penggunaan warnawarna yang terang, seperti hijau, kuning, biru, dan putih turut mendukung eye catching ilustrasi tersebut. Warna-warna tersebut tergolong menarik perhatian mata, karena lebih memantulkan sinar ke mata pengamat (Heller, 1988: 102). Di dalam poster tersebut, digambarkan karakter utama beserta karakter pendukung lainnya berlari dengan tampilan yang perspektif sehingga menimbulkan kesan kedalaman.

Tipografi judul merupakan kelompok display yang memiliki serif. Penyajian tipografi judul memiliki kesan yang menyatu dengan ilustrasi melalui penggunaan warna dan tekstur yang sama. Terlebih terdapat ornamen pada huruf " $S$ ", berupa sepasang telinga sesuai dengan telinga pada figur utama film. Tipografi credit title menggunakan uppercase dari kelompok display, namun berbeda dengan typeface judul. Serta ditampilkan dengan point yang relatif lebih kecil dibandingkan judul. Sehingga arah gerak mata tertuju ke credit title usai mengamati ilustrasi dan title.

Berdasarkan tanda-tanda yang terdapat pada poster film animasi Shrek, dapat diintepretasikan bahwa terdapat satu garis besar tema film, yakni dongeng. Sub title berada di puncak bidang poster menekankan "The Greatest Fairy Tale Never Told”, dengan demikian posisi sub title yang berada diatas bidang poster merupakan awal visual pathway mata pengamat. Untuk selanjutnya diarahkan pada ilustrasi dan judul. Sub title memiliki typeface yang tidak mencolok, tetapi komposisinya secara keseluruhan menunjukkan peran yang cukup penting.

Pada awal peluncuran Ice Age, film ini mendapat sambutan yang sangat baik dari khalayak. Film ini menduduki box office di Amerika Utara dan masuk dalam daftar salah satu film terbaik di seluruh dunia (http://www.allmovie.com).

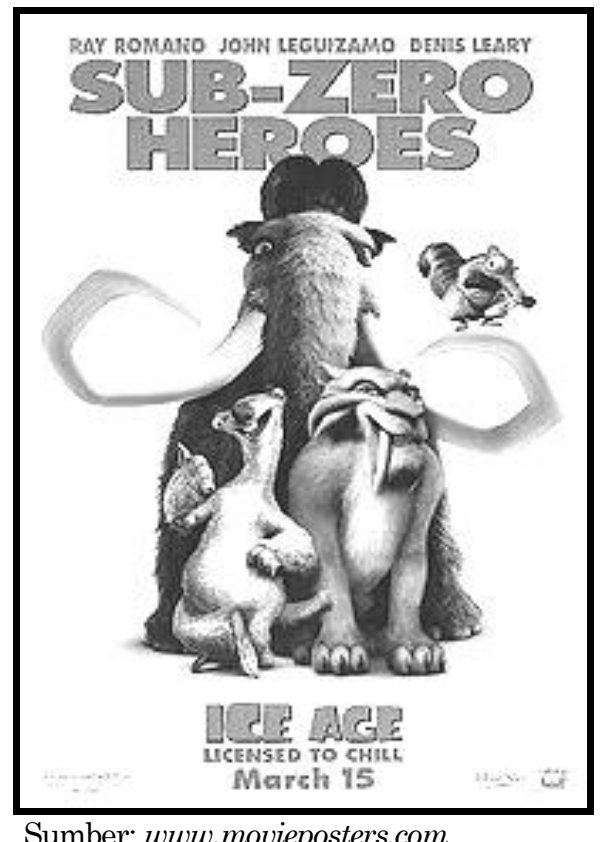

Gambar 3. Poster Film Animasi Ice Age (2002)

Ilustrasi desain poster tersebut bersifat teratur dan simetris. Peletakan ilustrasi hanya pada bagian pusat bidang. Di luar itu, berupa white space yang dikombinasikan dengan peletakan tipografi yang memuat judul, sub judul, dan credit title. Penataan komposisi tersebut seolah-olah membagi bidang poster menjadi tiga bagian, yaitu bagian atas, tengah, dan bawah. Untuk bagian atas berisi sub title "Sub-Zero Heroes" dan credit title yang memuat nama pemain, produser, sutradara dan keterangan pendukung lainnya, bagian tengah berisi ilustrasi serta title dan credit title pada bagian bagian bawah.

Adanya kesan/ekspresi dari tiap-tiap karakter dalam film menjadi kekuatan utama dalam penyajiannya. Penggunaan warna-warna yang gelap (coklat) pada ilustrasi sangat mendukung penciptaan karakter yang mendekati realis. Didukung pula dengan warna putih pada background menjadikan ilustrasi lebih menonjol. Terlebih setting film ini ada pada zaman bumi masih dipenuhi es/salju, dimana es/salju identik dengan warna putih. Secara umum, perancang poster mengharapkan penggambaran kondisi dalam film dengan mendramatisasi elemen visual poster.

Tipografi judul menggunakan jenis typeface yang tebal dan tidak memiliki serif. Tipografi sub judul disajikan dalam ukuran yang jauh lebih besar 
dibandingkan tipografi judul. Selain itu, penggunaan uppercase dan san serif pada sub judul sangat membantu mata pengamat untuk dapat membaca pesan dengan benar. Sub judul menyampaikan informasi secara sekilas mengenai tema cerita dalam film. Sehingga perancang membuatnya lebih dominan dibandingkan tipografi judul. Terlebih diletakkan di bagian atas bidang poster.

Berdasarkan tanda-tanda yang terdapat pada poster film animasi Ice Age diatas, dapat diintepretasikan bahwa film animasi yang diposterkan tersebut bercerita tentang kisah kepahlawanan yang dikemas berupa fabel. Tanda yang sangat jelas menekankan informasi ini terdapat pada $s u b$ title yang dominan dalam poster. Sub title "SubZero Hero" dikomposisikan diatas ilustrasi dengan point tipografi yang lebih besar dibandingkan judul film itu sendiri. Posisi sub title yang berada diatas ilustrasi merupakan permulaan visual pathway mata pengamat. Dengan demikian, sebelum mengetahui informasi lebih lanjut, pengamat dapat memahami tema film animasi yang diposterkan tersebut. "Sub-Zero" jika diartikan secara harfiah mengacu pada suhu dibawah nol derajat celcius atau sangat dingin. Sesuai dengan setting film animasi, yakni pada zaman es. Akan tetapi sub title ini memiliki makna konotasi, "Sub-Zero" dianalogikan sebagai "cool". "Cool" dalam Bahasa Inggris memiliki makna ganda, yakni dingin dan keren. Jadi, jika dikombinasikan dengan "Hero", menjadi "Sub-Zero Hero" diartikan sebagai pahlawan yang sangat keren.

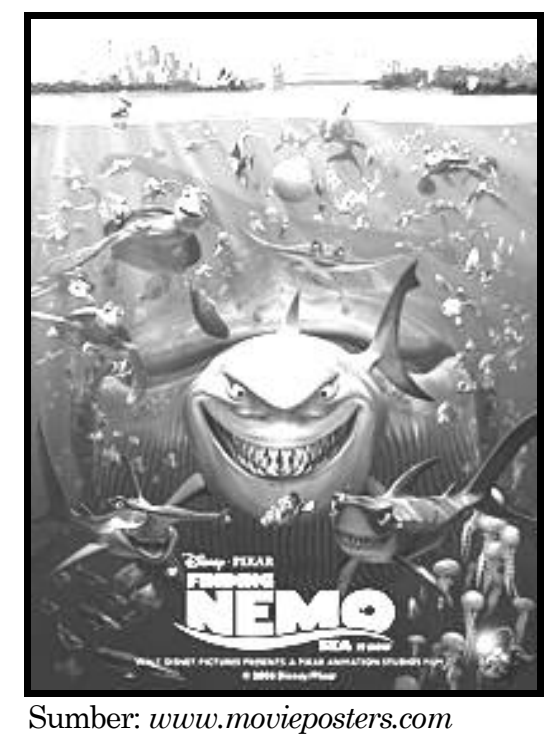

Gambar 4. Poster Film Animasi Finding Nemo (2003)

Finding Nemo merupakan film animasi tersukses dari jauh melampaui $U p$ dan The Incredibles. Pixar sebagai produsen film animasi Finding
Nemo dari situs pengkritik internasional dan profesional, Rotten Tomatoes.

Layout desain masih disajikan secara simetris dan mengutamakan keseimbangan. Secara keseluruhan, komposisi poster tersebut masih dirasa penuh oleh ilustrasi, sehingga pengamat hanya memiliki sedikit ruang untuk diam dan mengamati salah satu bagian poster tersebut.

Ilustrasi banyak menarik perhatian mata pada poster film ini, dimana sebagian besar karakter dalam film "tumpah" memenuhi bidang poster. Pada ilustrasi poster ditampilkan karakter utama yang disejajarkan dengan karakter-karakter lainnya dalam film, secara tidak langsung pengamat ditujukan pada perbandingan ukuran tubuh masing-masing karakter. Berdasarkan perbandingan ukuran tubuh tersebut, kesan realis didapatkan. Warna biru mendominasi penampilan ilustrasi poster. Namun, penerapan warna orange yang menyala pada salah satu karakter film yang berada tepat di perpotongan vertikal bidang poster menjadi fokus keseluruhan ilustrasi poster ini. Yakni, dititikberatkan pada karakter utama film, seekor ikan badut yang kecil, "Nemo".

Tipografi judul dibuat dengan baseline yang melengkung. Untuk menimbulkan kesan yang bebas dan mengalir seperti air. Akan tetapi, tetap berusaha menjaga konsistensi bentuk, ukuran, dan kerning.

Warna-warna yang dipilih dalam desain poster ini adalah warna-warna yang terang tepi teduh. Adapun warna-warna yang dimaksudkan adalah biru, hijau, ungu, orange, dan coklat. Kombinasi yang kontras antara biru pada sebagian besar ilustrasi dan orange pada karakter utama "Clown Fish" menyebabkan mata langsung tertuju pada warna orange.

Berdasarkan tanda-tanda yang terdapat pada poster film animasi Finding Nemo diatas, dapat diintepretasikan bahwa tema film animasi yang diposterkan adalah cerita fabel binatang laut. Untuk lebih tepatnya informasi yang disampaikan, penyajian tipografi judul, yakni “ $O$ " pada "NEMO" terdapat counter (:bidang kosong pada badan huruf) yang berupa siluet ikan kecil. Siluet tersebut mengacu pada bentuk badan figur utama. Dengan demikian, dapat diketahui bahwa figur utama dalam film tersebut adalah seekor clown fish bernama "Nemo".

The Incredibles berkisah tentang keluarga yang memiliki suatu kelebihan dibandingkan manusiamanusia pada umumnya. Mereka memiliki naluri 
untuk menolong orang lain melalui kekuatan yang dimiliki. Akan tetapi karena kesalahan-kesalahan yang tidak disengaja oleh mereka, masyarakat menjadi tidak menyukai mereka, bahkan menolak setiap pertolongan yang diberikan.

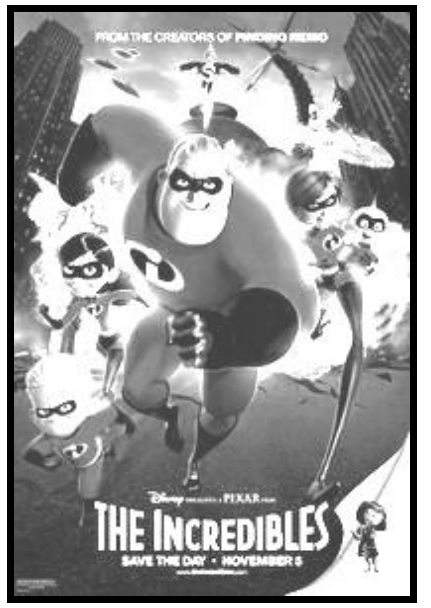

Sumber: www.movieposters.com

Gambar 5. Poster Film Animasi The Incredibles (2004)

Layout desain secara signifikan tidak banyak berubah dari poster-poster film sebelumnya, masih terlihat simetris dan teratur. Poster film The Incredibles ini mengandalkan ilustrasi sebagai kekuatan utama dalam penyajiannya.

Dari ilustrasi tersebut, diharapkan pengamat sudah dapat memahami tema cerita film yang diposterkan tersebut. Penggunaan warna-warna yang terang, seperti merah, orange, dan kuning turut mendukung eye catching ilustrasi tersebut. Di dalam poster tersebut, digambarkan karakter utama beserta karakter pendukung lainnya berlari seolah-olah keluar dari bidang poster tersebut, terlebih ditampilkan dengan perspektif "satu titik lenyap" sehingga kesan kedalaman didapat melalui ilustrasi poster ini.

Dari tanda-tanda yang terdapat pada poster film animasi The Incredibles diatas, dapat diintepretasikan bahwa tema film animasi ini berkenaan dengan kisah kepahlawanan sekelompok manusia dengan kekuatan super. Tema tersebut diindikasikan dengan penyajian ilustrasi berupa ledakanledakan khas pertempuran. Didukung pula dengan penyajian ilustrasi karakter-karakter utama yang mengenakan kostum superhero, meliputi pakaian yang ketat dengan sebuah simbol di dada, sarung tangan, sepatu boot, dan topeng. "Incredibles" dalam Bahasa Indonesia berarti luar biasa. "Incredibles" mengacu pada kekuatan lebih yang tidak dimiliki oleh semua manusia pada umumnya.

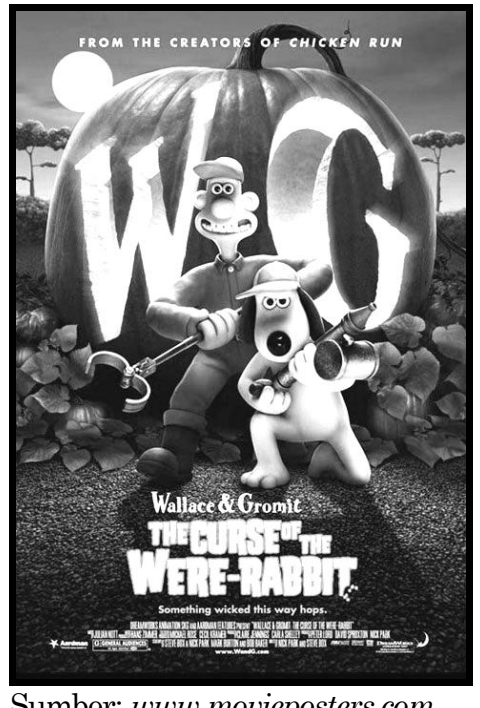

Sumber: www.movieposters.com

Gambar 6. Poster Film Animasi Wallace \& Gromit: the Curse of Were-Rabbit (2005)

Wallace and Gromit: The Curse of the Were-Rabbit merupakan film animasi stop motion (claymation) yang diproduksi oleh DreamWorks Animation.

Layout desain bersifat teratur, simetris dan seimbang. Dalam desain poster tersebut, bidang poster dibagi menjadi dua bagian, yaitu bagian atas merupakan ilustrasi dan bagian bawah merupakan bagian judul dan credit title.

Ilustrasi merupakan pusat perhatian dari poster tersebut, sebab sebagian besar bidang poster didominasi oleh ilustrasi. Ekspresi figur dalam ilustrasi tersebut menjadi kekuatan utama dalam penyajiannya.

Tipografi judul menggunakan jenis typeface yang tebal dan tidak memiliki serif. Pemakaian jenis san serif ini menimbulkan kesan yang kuat. Tipografi judul pada "Wallace \& Gromit" merupakan kombinasi uppercase dan lowercase. Penyajian dalam format center untuk menghadirkan kesan yang teratur dan "seolah-olah" simetris. Sama halnya dengan judul "Wallace \& Gromit" typeface sub title disajikan semakin ke bawah semakin mengecil.

Warna yang digunakan banyak didominasi oleh warna gelap seperti coklat. Selain itu, dikombinasikan warna biru dan orange pada bagian figur untuk memberikan aksentuasi terhadap objek utama.

Berdasarkan tanda-tanda yang terdapat pada poster film animasi diatas, dapat diintepretasikan bahwa tema Wallace \& Gromit adalah film animasi horor. Sebuah labu identik dengan 
perayaan Halloween di negara-negara barat. Labu pada ilustrasi mengindikasikan genre film animasi ini. Didukung pula dengan penggunaan warnawarna gelap yang terkesan suram. Sub title "something wicked this way hops" memberikan gambaran secara umum tentang jalan cerita film ini, dimana terdapat suatu kejahatan yang datang dengan melompat, padahal pada umumnya kejahatan datang dengan mengendap-endap. Typeface judul memiliki karakteristik yang khas, yakni badan huruf dan baseline yang acak turut mendukung thriller film animasi ini.

Jadi, berdasarkan keterkaitan antar tanda visual pada poster dengan tema film animasi, maka simpulan dari poster film animasi diatas bahwa film animasi Wallace and Gromit: The Curse of the Were-Rabbit merupakan film animasi bergenre horror comedy.

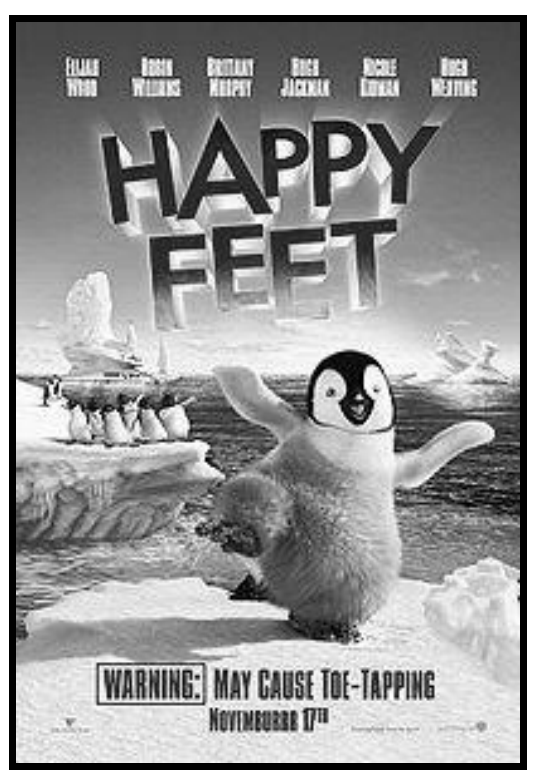

Gambar 7. Poster Film Animasi Happy Feet (2006)

Film tentang penguin ini disutradarai oleh George Miller dan diproduksi oleh Warner Bros. Berdasarkan penyajian audio visual dan tema cerita, Happy Feet memperoleh berbagai penghargaan, termasuk Academy Awards 2006, sebagai The Best Animated Feature.

Layout desain poster masih disajikan secara simetris dan mengutamakan keseimbangan. Posisi badan figur dalam poster yang unbalance dikombinasikan dengan background figur-figur lainnya menjadikan komposisi poster ini seolah-olah balance dan simetris.

Ilustrasi masih banyak menarik perhatian mata dalam poster film ini. Pada ilustrasi poster ditampilkan karakter utama berpose sedemikian rupa dengan background karakter-karakter lainnya. Warna biru dan putih mendominasi penampilan ilustrasi poster. Namun, penerapan warna hitam pada figur utama yang berada di perpotongan vertikal bidang poster menjadi fokus keseluruhan ilustrasi poster ini. Yakni, dititikberatkan pada karakter utama film, seekor penguin yang sedang menari.

Tipografi judul dibuat dengan baseline yang tidak teratur. Untuk menimbulkan kesan yang bebas dan dinamis. Penggunaan warna merah dan kuning pada judul menciptakan kekontrasan pada poster secara keseluruhan.

Warna-warna yang dipilih dalam desain poster ini adalah warna-warna yang terang tepi teduh. Adapun warna-warna yang dimaksudkan adalah biru, putih, merah, dan kuning. Kombinasi yang kontras antara biru pada sebagian besar ilustrasi dan merah pada tipografi judul menyebabkan mata langsung tertuju pada warna merah. Terlebih pemilihan warna merah pada tipografi judul terletak di sekitar pusat perpotongan vertikal bidang poster.

Berdasarkan tanda-tanda yang terdapat pada poster film animasi Happy Feet diatas, dapat diintepretasikan bahwa genre film ini adalah film animasi musikal. Figur utama pada ilustrasi berupa seekor penguin dengan pose yang lincah. Pose yang tidak lazim untuk seekor penguin dengan kaki yang pendek. Pose penguin tersebut menggambarkan salah satu pose ketika menari. Berdasarkan penyajian ilustrasi tersebut, dapat diketahui bahwa film animasi ini merupakan film animasi yang diwarnai dengan alunan musik, lagu dan tarian. Sub title pada poster turut mendukung tema film animasi ini. Menggunakan typeface san serif yang tegas dan berwarna merah, sub title "WARNING: MAY CAUSE TOE-TAPPING' berusaha meyakinkan audiens bahwa film animasi dengan tema fabel ini merupakan film animasi musikal yang sanggup membuat penonton mengetukkan kaki seirama dengan musik dalam film.

Film animasi karya Pixar ini mendapat predikat film animasi dengan keuntungan tertinggi ketiga, tepat dibelakang Finding Nemo dan The Incredibles.

Layout desain bersifat teratur, simeris, dan seimbang. llustrasi merupakan pusat perhatian utama pada poster ini, karena ilustrasi berada pada perpotongan vertikal bidang serta didukung dengan ukuran yang memenuhi bidang. Penggunaan warna terang dan soft pada 
background dikombinasikan dengan warna-warna gelap pada figur dalam film, turut mengundang perhatian pengamat.

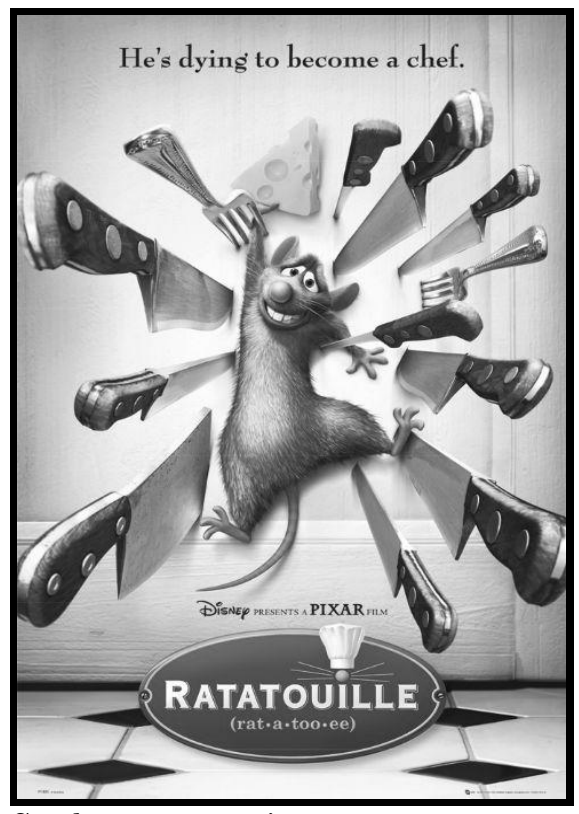

Sumber: www.movieposters.com

\section{Gambar 8. Poster Film Animasi Ratatouille (2007)}

Tipografi judul berasal dari kelompok display. Jenis typeface yang digunakan tersebut memiliki serif yang kurang tampak jelas, sehingga disebut hybrid serif. Pemberian shadow pada penulisan typeface tersebut memberikan kesan yang tegas bagi keterbacaan judul. Dalam penyajiannya, posisi tipografi berada pada sebuah bidang oval berwarna biru. Pada huruf "i" terdapat ornamen, yakni simbolisasi hidung, kumis tikus serta sebuah topi chef. Hal ini memberikan aksentuasi pada penampilan judul.

Dari tanda-tanda yang terdapat pada poster film animasi Ratatouille, dapat diintepretasikan bahwa tema film animasi ini adalah fabel dalam dunia tata boga. Gambaran umum tentang cerita film ini diperoleh melalui penyajian sub title "He's dying to become a chef' yang diletakkan diatas ilustrasi sebagai permulaan visual pathway mata pengamat. Ilustrasi turut mendukung tema film animasi tentang masak memasak ini.

$W A L L \cdot E$ dibuka untuk umum di Amerika Serikat dan Kanada pada 27 Juni 2008 dan mendapat pemasukan 23,1 juta dolar Amerika pada hari pembukaannya.dan pada akhir pekan pembukaannya, sehingga mengukuhkan posisi $W A L L \cdot E$ di box office (http://www. boxofficemojo.com).

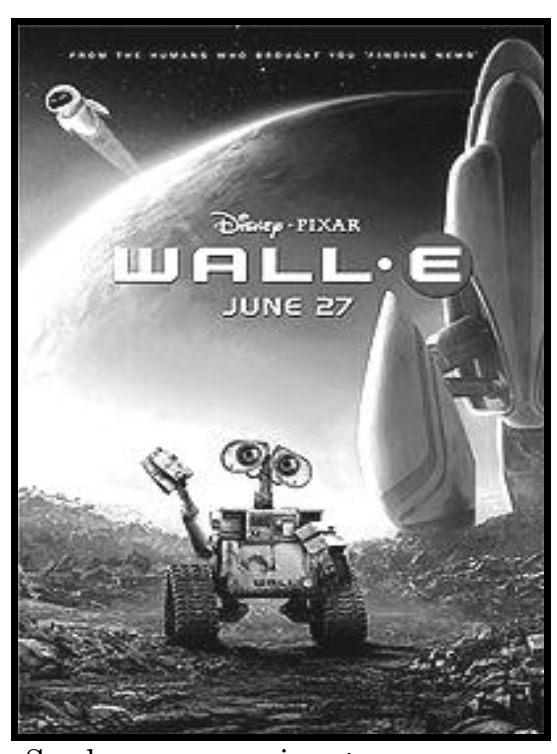

Sumber: www.movieposters.com

\section{Gambar 9. Poster Film Animasi $W A L L \cdot E$ (2008)}

Layout desain poster film ini masih didominasi oleh ilustrasi seperti poster-poster sebelumnya. Pada poster film $W A L L \cdot E$ ini ilustrasi menguasai seluruh bidang secara asimetris. Keseimbangan masih dibantu dengan adanya titik berat pada kedua sisi bidang poster, yakni sisi kanan dengan objek yang lebih besar diseimbangkan dengan arah pandang objek sisi kiri yang berlawanan. Pada umumnya, ilustrasi menyebar pada seluruh bidang poster, tetapi tidak secara simetris.

Ilustrasi yang dibuat secara komputerisasi merupakan pusat perhatian dari poster ini, sebab sebagian besar bidang poster masih diisi oleh ilustrasi. Penekanan poster film tersebut terletak pada figur/karakter dalam film. Terlebih figur yang dimaksud terletak di perpotongan vertikal bidang.

Tipografi judul menggunakan typeface yang terkesan geometris. Pemilihan warna putih untuk judul, semakin memperkuat kejelasan dan keterbacaan judul terutama di atas bidang warna gelap. Dengan demikian, kesan utama yang ditimbulkan adalah adanya ketegasan, dan keteraturan dalam ilustrasi.

Warna-warna yang digunakan dalam poster film animasi ini relatif sedikit. Pemakain warna yang terbatas ini menyebabkan kesan yang sederhana dan unik, tanpa meninggalkan penekananpenekanan yang diperlukan. Penggunaan wana biru, putih, dan hitam pada background memiliki kesan yang teduh dan dingin. 
Kombinasi warna kuning dan merah yang kontras menyebabkan mata langsung tertuju pada objek. Terlebih warna merah pada tipografi judul dan kuning pada figur film terletak di sekitar pusat vertikal bidang akan semakin menambah kekuatan pemantulan cahaya ke mata.

Secara keseluruhan, desain poster tersebut memiliki karakter desain gaya modernism awal. Hal ini tampak pada penampilan ilustrasi yang menampilkan warna-warna secara terbatas namun cemerlang/terang (Heller, 1988; 42).

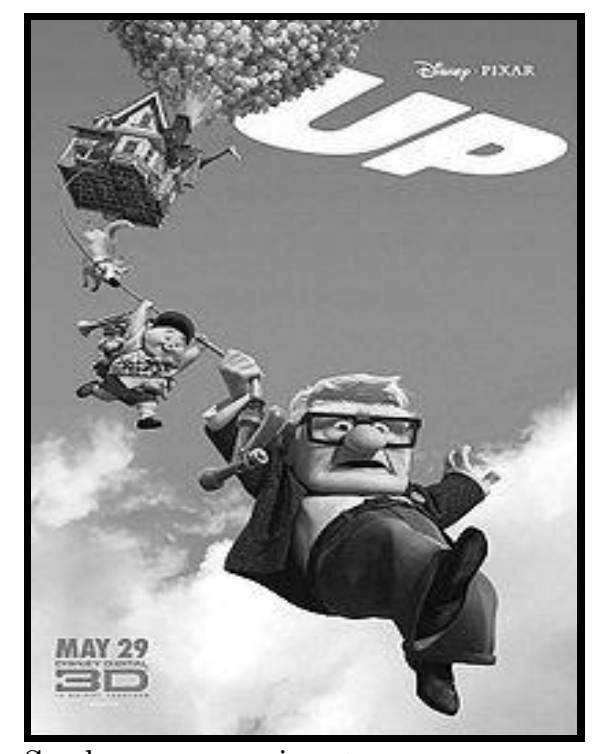

Sumber: www.movieposters.com

\section{Gambar 10. Poster Film Animasi UP (2009)}

Up diputar perdana pada 29 Mei 2009 dalam Cannes Film Festival, dan mencatat sejarah sebagai film animasi pertama yang diputar dalam acara tersebut (http://www.allmovie.com). Up berhasil memenangkan banyak penghargaan, terutama pada bagian Best Animated Feature dan Best Original Song.

Layout desain mengalami perubahan yang cukup signifikan pada poster film UP ini, karena format ilustrasi tidak lagi simetris seperti poster-poster film sebelumnya. Namun, meskipun format ilustrasi tidak simetris, keseimbangan secara visual masih terpenuhi, sebab keseimbangan dicapai melalui arah pandang dari objek ilustrasi (Curtiss, 1987: 46).

Tipografi judul seperti yang telah dijelaskan diatas, dibuat lebih menyatu dengan ilustrasi. Hal ini ditunjukkan dengan penyajian tipografi yang dibuat dalam perspektif. Karena judul tersebut disajikan dalam bentuk perspektif, maka baseline dan ukuran huruf yang menyusun judul juga menyesuaikan dengan perspektif ilustrasi ter- sebut. Dari segi pemilihan warna judul, tipografi judul juga dapat dikatakan sudah menyatu dengan ilustrasi. Karena menggunakan warna putih yang dekat dengan warna langit pada background ilustrasi.

Warna-warna yang digunakan pada poster ini merupakan kombinasi warna-warna pastel yang terang dan meriah. Sentuhan warna gelap pada figur film memberikan aksentuasi tersendiri. Sehingga ilustrasi tidak tampak datar.

Dari tanda-tanda yang disajikan poster film animasi $U P$ ini dapat terlihat tema film animasi ini adalah kisah petualangan yang unik. Penyajian ilustrasi dengan perspektif dan komposisi yang asimetris serta tipografi judul yang mengikuti sudut pandang ilustrasi mendorong terciptanya kesatuan tema dalam film. Penyajian ilustrasi dan tipografi judul yang harmonis tersebut, sangat mendukung penyampaian informasi tentang film sebelum audiens menontonnya.

\section{Kesimpulan}

Berdasarkan simpulan analisis tanda-tanda visual di atas dapat disimpulkan bahwa pemilihan tanda-tanda visual yang digunakan dalam poster sangat diperhatikan secara detil, meliputi penyajian ilustrasi, tipografi dalam judul dan sub judul serta komposisi/layout secara keseluruhan. Dimana setiap tanda tersebut terjalin satu sama lain untuk menyampaikan suatu informasi yang saling berkesinambungan tentang tema film yang diposterkan.

Teknologi Computer Generated Imagery (CGI) mendominasi teknik film animasi selama 10 (sepuluh) tahun terakhir. Fenomena ini merupakan hal yang wajar, mengingat Amerika Serikat sebagai perwakilan negara-negara barat merupakan pioneer terciptanya film animasi. Sehingga dapat diakui bahwa kemajuan teknologinya lebih terdepan dibandingkan negara-negara lain di dunia. Computer Generated Imagery (CGI) merupakan aplikasi dari computer graphics, khususnya $3 D$ computer graphics yang berfungsi untuk penciptaan karakter dalam film, penambahan efek-efek khusus, atau memperhalus kualitas grafis dari sebuah film animasi (Concept Magazine vol. 4 Edisi 22. 2008: 58). Film animasi Toy Story (Pixar, 1995) dan a Bug's Life (Pixar, 1998) merupakan titik awal lahirnya aplikasi CGI secara penuh pada sebuah film. Walt Disney Company menyadari manfaat CGI yang luar biasa, sehingga melakukan transisi dari animasi tradisional ke animasi berbasis CGI dengan bekerjasama dengan Pixar Studio. 
Penyajian tanda-tanda visual pada poster film animasi produksi Amerika Serikat 10 (sepuluh) tahun terakhir ini memiliki kecenderungan tertentu. Pertama, ilustrasi pada poster film animasi Amerika Serikat cenderung mendominasi bidang poster. $3 / 4$ bidang poster merupakan ilustrasi, sedangkan sisanya memuat tipografi, baik judul, sub judul, maupun credit title. Sehingga tampilan ilustrasi menjadi perhatian utama perancang poster. Ilustrasi poster film animasi Amerika Serikat cenderung menekankan pada tampilan ekspresi figur utama sebagai daya tarik. Hal ini dapat dilihat pada sebagian besar poster film animasi Amerika Serikat, yakni Shrek, Ice Age, The Incredibles, Wallace \& Gromit, Happy Feet, Ratatouille, $W A L L \cdot E$, dan UP. Kedua, pemilihan typeface judul cenderung dari kelompok Display dengan karakteristik san serif. Kelompok Display memiliki karakteristik yang berorientasi pada kepentingan display, sehingga tampilannya selalu berupaya agar lebih menarik perhatian mata pengamat, akan tetapi terbatas pada keperluan teks yang relatif singkat. Ketiga, sebagian besar poster film animasi Amerika Serikat menggunakan kombinasi warna-warna variatif dan cukup kompleks, tanpa mengabaikan emphasis penyajian tanda-tanda visual poster. Keempat, komposisi/ layout cenderung simetris, dengan format center dan berusaha menyeimbangkan bidang positif dan bidang negatif. Namun, perlahan komposisi asimetris mulai diterapkan pada poster film animasi $W A L L \cdot E$ dan $U P$. Kedua poster tersebut, memanfaatkan keseimbangan asimetris/informal, dimana komposisi elemen-elemen visual didasarkan pada kekontrasan berat dan arah. Dimana berat mengacu pada kekuatan/dominasi elemen pada bidang desain, sedangkan arah merupakan pergerakan semu dari elemen desain. Keseimbangan ini cenderung lebih menarik perhatian pengamat karena mengajak mata pengamat bergerak secara aktif dalam komposisi untuk menjelajahi bidang desain. Hal ini mampu menahan perhatian pengamat lebih lama dibandingkan komposisi keseimbangan simetris.

\section{Daftar Pustaka}

Concept Magazine vol. 4 Edisi 22. 2008. Jakarta: PT. Concept Media.

Curtiss, Deborah. 1987. Introdution to Visual Literacy. New Jersey: Prantice-Hall.

Glover, Savion. 15 Maret 2007. Happy Feet Won't Debut in IMAX 3D. (Online). (http://www. imax.com, diakses 7 April 2010).

Heller, Steven. 1988. Graphic Style From Victorian to Post Modern. London: Thames and Hudson limited.

Homby. 1995. Animation in Oxford Advanced Learner's Dictionary. New York: Oxford University Press.

McCarthy, Helen. 1993. Anime a Beginner's Guide to the World of Japanesse Animation. London: Titan Books Ltd.

Perfect, Christopher. 1992. The Complete Typographer. Massachusetts: Rockport publisher, Inc.

Salim, Peter. 1985. Animation in the contemporary English-Indonesia Dictionary. Jakarta: Modern English Press.

Sihombing, Danton. 2001. Tipografi dalam Desain Grafis. Jakarta: PT. Gramedia Pustaka Utama Jakarta.

Sobur, Alex. 2009. Semiotika Komunikasi. Bandung: PT Remaja Rosdakarya.

---. 2009. Analisis Teks Media. Bandung: PT Remaja Rosdakarya.

Stevenson, George. 1992. Graphics Art Encyclopedia, 1st ed. New York: APA.

Szymanski, Mike. 10 Oktober 2005. Wallace \& Gromit. (Online). (http://www.scifi.com, diakses 10 April 2010).

Tim, Stack. 18 Oktober 2010. Festival de Cannes: Shrek. (Online). (http://www.festival-cannes. com, diakses 7 April 2010).

http://www.allmovie.com

http://www.boxofficemojo.com

http://www.movie-winners.com

http://www.moviewinners.com 